\title{
Morphological Characterization and Classification of Open-pollinated Sweet Corn Cultivars
}

\author{
Pedro Revilla and W.F. Tracy ${ }^{1}$ \\ Department of Agronomy, University of Wisconsin-Madison, WI 53706 \\ Additional index words. Zea mays, maize, plant morphology, numerical taxonomy
}

\begin{abstract}
Sweet corn is one of the most important vegetable crops in the United States, however the morphology and phylogeny of open-pollinated sweet corn cultivars has not been studied. Fifty eight open-pollinated sweet corn cultivars were characterized with thirty-four descriptors to provide information for breeders interested in broadening the genetic base of sweet corn. Principal component analysis and cluster analysis were performed to classify sweet corn cultivars based on morphology. Also, relationships among morphological variables in this set of cultivars were determined. The general ordination of cultivars followed an axis representing earliness, and plant, leaf, and tassel size, while ear and kernel attributes were less variable. The morphological variability among all of the widely used sweet corn cultivars, except 'Country Gentleman', was not greater than the variability found among the 'Golden Bantam' strains. Based on morphology, 52 of the cultivars could be considered as one race, which we propose be called 'Northeastern Sweets'. These may be a subset of the race 'Northern Flint'. Five of the remaining cultivars are from the north-central or southwestern United States and may represent races from those areas. The sixth cultivar is 'Country Gentleman', a commercially important sweet corn cultivar. Due to the importance of 'Country Gentleman' and the introgression of nonsweet germplasm into modern sweet corn, we believe that sweet corn should be defined based on its use as a vegetable and on the presence of one or more genes that increase sugar levels in the endosperm.
\end{abstract}

While sweet corn is one of the most important vegetable crops in the United States, it is poorly represented in the USDA-ARS National Plant Germplasm System. Tapley et al. (1934) identified over 800 open-pollinated (OP) sweet corn cultivars, most of which originated in the northeastern United States. Today there are -25 sweet corn accessions comprising OP cultivars from the United States and Canada at the North Central Regional Plant Introduction Station (NCRPIS) at Ames, Iowa. Another source for OP cultivars is the Seed Savers Exchange (Adelman et al., 1993). The 1993 Seed Savers yearbook lists $\approx 3.5$ cultivars, not including those obtained by seed savers from NCRPIS.

With the advent of hybrid sweet corn, development of OP cultivars ended and the OP cultivars served as source material for inbred development. However, inbred extraction concentrated, with a few notable exceptions, on three cultivars: 'Golden Bantam', 'Stowell's Evergreen', and 'Country Gentleman' (Huelson, 1954; Tracy, 1993; Gerdes and Tracy 1994).

Alleles useful for sweet corn improvement may be present in the few OP cultivars still in existence. However, if the germplasm is to be used it should be collected and characterized. Characterization of morphological variability will allow breeders to identify accessions with desirable characteristics such as earliness, disease resistance, or improved ear morphology. Characterization and grouping of germplasm will allow breeders to avoid duplication in sampling populations. Also, in the absence of pedigree records or information on combining ability it would be useful to organize the collection based on morphology. This may allow breeders to identify potential combining ability groups.

Numerical taxonomy and genetic relationships of maize races and cultivars has been the subject of many research programs over

Received for publication 28 Mar. 1994. Accepted for publication 25 July 1994 Contribution from the Wisconsin Agricultural Experiment Station Research supported by the College of Agriculture and Life Sciences, Univ. of WisconsinMadison, and the Comisión Interministerial de Ciencia y Tecnologia of Spain. The cost of publishing this paper was defrayed in part by the payment of page charges. Under postal regulations, this paper therefore must be hereby marked advertisement solely to indicate this fact.

${ }^{1}$ To whom reprint requests should be addressed. the past 50 years (Wellhausen et al., 1957; Bird and Goodman, 1977; Camussi, 1979,1980; Sanchez and Goodman, 1992: Llaurado and Moreno-Gonzalez, 1993). But, neither the relationships nor the diversity among sweet corn cultivars have been systematically investigated. Many tools are now available to study relationships among cultivars, including various types of molecular markers; however, morphological characterization is the first step in the description and classification of germplasm (Smith and Smith, 1989).

Our objective was to characterize and classify OP sweet corn cultivars, with primary emphasis on morphological traits.

\section{Materials and Methods}

Fifty-eight sweet corn cultivars were obtained from farmers, gardeners, and hobbyists associated with the Seed Savers Exchange (Adelman et al., 1992, 1993), NCRPIS, and the collection of the Univ. of Wisconsin-Madison (Table 1). Based on our examination of the NCRPIS records, Seed Savers Yearbooks (Adelman et al., 1993), and seed catalogs, this represents approximately $95 \%$ of the North American sweet corn OP cultivars available to the public. Seed of the cultivars were planted on 15 May and 18 June 1993 at the West Madison (Wis.) Agricultural Research Station in a Plano silt loam (fine-silty, mixed, mesic Typic Argiudolls). The first planting date resulted in good environmental conditions for sweet corn production while the second planting was exposed to two main stress factors that are typical in the upper Midwest: severe common rust (Puccinia sorghi) infestation and cool late season growing conditions. The experimental design was a randomized complete block with two replications per planting date. Two-row plots, $5.3 \mathrm{~m}$ long with $76 \mathrm{~cm}$ between rows, were overplanted with 30 seeds per row and thinned to an evenly spaced stand of 15 plants per row. Weeds were controlled with 2.3 liters $\cdot \mathrm{ha}^{-1}$ cyanazine, 2.3 liters $\cdot \mathrm{ha}^{-1}$ alachlor, and cultivation.

Many authors have suggested sets of characters appropriate for classification or taxonomy in maize (Goodman and Paterniani, 1969; Sanchez et al., 1993). Since the main goal of this research was a practical characterization of sweet corn germplasm for 
Table 5. Effect of infestation level on ear damage by European corn borer on resistant sweet corn breeding lines ${ }^{z}$.

\begin{tabular}{lccc}
\hline \hline $\begin{array}{l}\text { Entries across levels of infestation } \\
1989\end{array}$ & & \\
\cline { 2 - 4 } & \multicolumn{2}{c}{1990} \\
\hline Lines & Acceptable ears $(\%)^{y}$ & Lines & Acceptable ears $(\%)$ \\
\hline 96 & $77 \mathrm{a}$ & 2667 & $94 \mathrm{a}$ \\
98 & $75 \mathrm{a}$ & 620 & $88 \mathrm{ab}$ \\
169 & $63 \mathrm{ab}$ & 618 & $86 \mathrm{ab}$ \\
132 & $54 \mathrm{~b}$ & 621 & $80 \mathrm{~b}$ \\
Jubilee 1 & $9 \mathrm{c}$ & 2670 & $55 \mathrm{c}$ \\
Jubilee 2 & $2 \mathrm{c}$ & Jubilee & $10 \mathrm{~d}$ \\
LSD $_{0.01}$ & 20 & & 13
\end{tabular}

Levels of infestation across entries (lines and controls)

\begin{tabular}{lcc} 
Level & \multicolumn{2}{c}{ Acceptable ears $(\%)$} \\
\cline { 2 - 3 } (no. of larvae) & 1989 & 1990 \\
\hline 50 & $57 \mathrm{a}$ & $79 \mathrm{a}$ \\
100 & $42 \mathrm{ab}$ & $70 \mathrm{ab}$ \\
150 & $32 \mathrm{~b}$ & $64 \mathrm{~b}$ \\
200 & $39 \mathrm{~b}$ & $62 \mathrm{~b}$ \\
$\mathrm{LSD}_{0.01}$ & 15 & 10
\end{tabular}

$\overline{\overline{ }}$ Means within column followed by the same letter do not differ $(P=0.01)$.

'Ears scoring 3 or lower on the 1 to 9 visual rating scale (Table 2) for ear damage were classed as acceptable for commercial processing.

larvae might leave an ear with a high population.

Jarvis and Guthrie (1987) applied one, two, four, and eight egg masses per ear $(\approx 30$ eggs/mass) to compare kernel damage in popcorn, dent corn, and sweet corn. Damage was determined by counting the number of kernels damaged, and the egg masses were not placed at the ear tip. 'Silver Queen' and 'Tahitian Hi-Sugar', the two sweet corn hybrids used, were considered susceptible, with damage ranging from 7.9 and 19.5 kernels per ear, respectively, at one egg mass, to 17.6 and 64.8 at eight egg masses. Location of damage was not considered and actual hatch of eggs per mass was not reported. In our research, ears arbitrarily were classed as acceptable if receiving up to $1 \%$ kernel damage, with damage occurring only at the ear tip. On an average hybrid ear, $1 \%$ kernel damage would equal about five kernels. Ears having one or more kernels damaged by larval penetration into the. side or base of the ear, however, were not considered acceptable.

In conclusion, moderate ear-feeding resistance was confirmed for the several breeding lines, and most lines transmitted a significant level of resistance in testcross combination. Resistance generally was maintained when the ear silk channel was shortened, or when larval numbers were increased. While resistance levels comparable to those of the breeding lines used in this research have been shown by Bolin et al. (1993) and Hutchison et al. (1992) to have potential in reducing insecticide needs, even higher levels undoubtedly will be desirable in ECB resistance management by the sweet corn industry. The industry has long had as its goal a zero tolerance for product contamination by the ECB, and the processing sector also continues to have a strong interest in eliminating need for costly hand-trimming of ears.

\section{Literature Cited}

Andrew, R.H. and J.R. Carlson, Jr. 1976. Evaluationof sweet corn inbreds for resistance to European corn borer. J. Amer. Soc. Hort. Sci. 101:9799.

Bolin, P.C., W.D. Hutchison, and D. Davis. 1993. Dual impact of resistant hybrids and Bacillus thuringiensis for European corn borer control, p.
67-84. In: 1993 Processing crops manual and proceedings. vol. 5. Midwest Food Processors Assn., Madison, Wis.

Davis, D.W., D.A. Andow, and W. D. Hutchison. 1993. Registration of three European corn borerresistant sweet corn germplasm lines: A684su, A685su, and A686su. Crop Sci. 33:1422-1423.

Davis, D., D. Andow, W. Hutchison, K. Sauter, and G. Gingera. 1992. Development of resistance in sweet corn to European corn borer, p. 6974. In: 1992 Processing crops manual and proceedings. vol. 4. Midwest Food Processors Assn., Madison, Wis.

Davis, D.W., G.R. Gingera, and D.K. Warnock. 1994. Breeding for resistance to European corn borer and other pests in sweet corn, p. 8592. In: 1994 Processing crops manual and proceedings. vol. 6. Midwest Food Processors Assn., Madison, Wis.

Davis, D.W. and S.L. Grier. 1978. Resistance of some sweet corn germplasm to second-brood European corn borer. Ann. Plant Resistance to Insects Nwsl. 4:23-25.

Grier, S.L. and D.W. Davis. 1980. Infestation procedures and heritability of characters used to estimate ear damage caused by second-brood European corn borer (Ostrinia nubilalis, Hübner) on corn. J. Amer. Soc. Hort. Sci. 105:3-8.

Hutchison, W.D., D.W. Davis, P.C. Bolin, D.W. Bartels, and V. Fritz. 1992. Alternative methods for European corn borer control and firstyear results on the impact of 1st-generation infestations on sweet corn yield and quality, p. 321-326. In: 1992 Processing crops manual and proceedings. vol. 4. Midwest Food Processors Assn., Madison, Wis.

Jarvis, J.L. and W.D. Guthrie. 1987. Ecological studies of the European corn borer (Lepidoptera: Pyralidae) in Boone County, Iowa. Environ. Entomol. 16:50-58.

Lamb, E.M., D.W. Davis, and D.A. Andow. 1994. Mid-parent heterosis and combining ability of European corn borer resistance in maize. Euphytica 72:65-72.

Ortega, A., S.K. Vasal, J. Mihm, and C. Hershey. 1980. Breeding for insect resistant maize, p. 371-419. In: F.G. Maxwell and P.R. Jennings (eds.). Breeding plants resistant to insects. Wiley, New York.

Ritchie, S.W. and J.J. Hanway. 1982. How a corn plant develops. Iowa State Univ. Coop. Ext. Serv. Spec. Rpt. 48.

Waiss, A.C., B.G. Chan, C.A. Elliger, B.R. Wiseman, W.W. McMillian, N.W. Widstrom, M.S. Zuber, and A.J. Keaster. 1979. Maysin, a flavone glycoside from corn silks with antibiotic activity toward corn earworn. J. Econ. Entomol. 72:256-258. 
breeding purposes, we chose 34 descriptors among those proposed by IBPGR (1991) (Table 2). Data were taken on ten randomly chosen plants per plot.

The following descriptors wererecorded (Table 2): days to $50 \%$ silking, days to $50 \%$ tasseling, anther color, silk color, foliage size, tassel type, kernel shape, leaf orientation, prolificacy, common rust (Puccinia sorghi) and smut (Ustilago maydis) susceptibility, leaf length, leaf width, number of leaves above the uppermost ear including the ear leaf, tiller number, plant height, ear height, tassel length, number of primary branches on tassel, number of secondary branches on tassel, number of tertiary branches on tassel, kernel type, kernel color, 1000 kernel weight, cob color, ear shape, kernel row arrangement, kernel row number, ear length, ear diameter, kernel length, kernel thickness, tip damage, and number of kernels per row.

Individual analyses of variance were performed for each of the 34 descriptors combined over planting dates. Cultivar effects were considered fixed while all other effects were random. To classify the sweet corn cultivars, principal component analysis (PCA) and cluster analysis (CA) (Sneath and Sokal, 1973) were computed, with the data combined across and within planting dates. PCA plot was drawn to show the ordination of the cultivars. The seven principal components with an eigenvalue larger than 1 were standardized to produce the Mahalanobis' generalized distances (Goodman, 1968) and a cluster was made with the unweighted pair-group method by using arithmetic averages (UPGMA) (Sneath and Sokal, 1973). Finally, the relationships among the traits were studied by means of a cluster analysis (procedure VARCLUS of SAS). All the analyses were conducted with the SAS system (SAS, 1989).

The data set is a mixture of continuous and discontinuous variables. Romesburg (1984) suggests several methods to analyze such data sets. But, methods based on making continuous variables discontinuous can also result in the loss of information (Romesburg, 1984). Dropping discontinuous variables from the analysis will also result in the loss of information. And all the variables included are considered important descriptors by IBPGR (IBPGR, 1991). On the other hand, Romesburg (1984) suggests that in some cases such variables may be combined in one analysis and result in accurate and useful information. In maize, discontinuous and continuous morphological variables have been used in combined analysis and resulted in useful classifications that were later supported by other measurements such as molecular markers (Smith and Smith, 1989). We felt that the loss of useful information

Table 2. Traits recorded ${ }^{2}$ in the 58 cultivars.

\begin{tabular}{|c|c|c|c|}
\hline Code & Trait & Unit & Description \\
\hline$\overline{\mathrm{DAS}}$ & Days to silking & Days & Days to $50 \%$ silking \\
\hline DAT & Days to tasseling & Days & Days to $50 \%$ tasseling \\
\hline $\mathrm{ANC}$ & Anther color & $1-4$ & $1=$ yellow, $2=$ mostly yellow with some purple, $3=$ mostly purple with some yellow, $4=$ purple \\
\hline SIC & Silk color & $1-4$ & $1=$ yellow, $2=$ mostly yellow with some purple, $3=$ mostly purple with some yellow, $4=$ purple \\
\hline FOL & Foliage & $1-7$ & $3=$ small to $7=$ large \\
\hline TAT & Tassel type & $1-3$ & $1=$ primary branches only, $2=$ secondary branches, $3=$ tertiary branches \\
\hline $\mathrm{KS} \Lambda$ & Kernel shape & $1-4$ & $1=$ shrunken to $4=$ rounded \\
\hline LEO & Leaf orientation & $1-2$ & $1=$ erect, 2 = pendant \\
\hline PRO & Prolificacy & Number & Ears/plant, plot average \\
\hline RUS & Rust sensitivity & $1-9$ & $1=$ very low to $9=$ very high \\
\hline SMU & Smut sensitivity & $1-9$ & $\mathrm{I}=$ very low to $9=$ very high \\
\hline LEL & Leaf length & $\mathrm{cm}$ & Ear leaf length \\
\hline LEW & Leaf width & $\mathrm{cm}$ & Ear leaf maximum width \\
\hline LEN & Leaf number & Number & Number of leaves above the uppermost ear including the ear leaf \\
\hline TIN & Tiller number & Number & Tillers/plant \\
\hline PLH & Plant height & $\mathrm{cm}$ & Stalk base to tassel base \\
\hline EAH & Ear height & $\mathrm{cm}$ & Stalk base to ear hase \\
\hline TAL & Tassel length & $\mathrm{cm}$ & First branch to top \\
\hline TBP & Tassel primary branches & Number & \\
\hline TBS & T. secondary branches & Number & \\
\hline TBT & Tassel tertiary branches & Number & \\
\hline KTY & Kernel type & 6 or 8 & $6=$ flint, $8=$ sweet \\
\hline KEC & Kernel color & $1,2,3,9,10$ & $1=$ white, $2=$ yellow, $3=$ purple, $9=$ red, $10=$ mixed \\
\hline KEW & Thousand kernel weight & $\mathrm{g}$ & \\
\hline $\mathrm{COC}$ & Cob color & 1 or 10 & $1=$ white, $10=$ mixed white and red \\
\hline EAS & Ear shape & 1 or 2 & $1=$ cylindrical, 2 = cylindrical - conical \\
\hline KRA & Kernel row arrangement & $1-2$ & $1=$ regular, $2=$ irregular \\
\hline RON & Row number & Number & Kernel rows/ear \\
\hline EAL & Ear length & $\mathrm{cm}$ & Ear base to top \\
\hline EAD & Ear diameter & $\mathrm{cm}$ & Contral ear diameter \\
\hline KEL & Kernel length & $\mathrm{cm}$ & $1 / 2$ ear minus cob diameter \\
\hline KTH & Kernel thickness & $\mathrm{cm}$ & Length of an ear segment/number of kernels \\
\hline $\mathrm{TID}^{y}$ & Tip damage & Number & Tip damaged ears out of 10 \\
\hline NKR & Number of kernels/row & Number & Number of kernels along ear \\
\hline
\end{tabular}

${ }^{\bar{z}}$ According to the definition of IBPGR (1991). + 10 is the value for mixed colors, this value has been added to the CIMMYT values, in the list of descriptors.

'This trait has been added to the IBPGR list of traits. 
Table 1. The 58 sweet corn cultivars included in this study and the source of seed.

\begin{tabular}{|c|c|c|c|}
\hline Code & Cultivar name & Provider & Former origin \\
\hline alg & ALTA GOLD & PI $219870^{2}$ & \\
\hline ana & ANASAZI & SS NM FL T $T^{y}$ & \\
\hline atk & ATKINSON & PI 198641 & \\
\hline aum & AUNT MARY'S & SS CA FI D & SS MO PE R 1992 \\
\hline bao & BABY ORCHARD & PI 219872 & \\
\hline bae & BANTAM EVERGREEN & SS MN EK M & SS WI HA M 1989 \\
\hline bay & BAXTER'S YELLOW & PI 255982 & \\
\hline bla & BLACK AZTEC & SS OR TH C & \\
\hline blm & BLACK MEXICAN & PI 162573 & \\
\hline cam & CAMPBELL & SS IA DR G & \\
\hline $\mathrm{clb}$ & CLEM BENNETT & SS OH DE J & SS WV NOS 1984 \\
\hline $\operatorname{cog}$ & COUNTRY GENTLEMAN & Univ. Wisconsin ${ }^{x}$ & \\
\hline dog & DORINNY & SS IA DR G & \\
\hline dou & DORINNY & PI 220866 & \\
\hline eae & FARLYY FVERGRFEN & PI 231297 & \\
\hline eaj & EARLY JUNE & PI 219876 & \\
\hline eap & EARLY PEARL & PI 228183 & \\
\hline gbb & GOLDEN BANTAM BURNELL & PI 255981 & \\
\hline gbm & GOLDEN BANTAM (MASS.) & PI 255977 & \\
\hline gbd & GOLDEN BANTAM (ND) & PI 219879 & \\
\hline gby & GOLDEN BANTAM (NY) & PI 255976 & \\
\hline gbw & GOLDEN BANTAM (WI) & Univ. Wisconsin & \\
\hline gem & GOLDEN EARLY MARKET & SS IA DR G & \\
\hline goe & GOLDEN GEM & PI 219880 & \\
\hline goi & GOLDEN GIANT & PI 231302 & \\
\hline gos & GOLDEN SUNSHINE & SS IA DR G & \\
\hline haw & HAYES WHITE & SS MN TJ J & SS MI KE R \\
\hline hid & HIDASTA & SS IA HA B ${ }^{\mathrm{w}}$ & \\
\hline hsi & HOOKER'S SWEET INDIAN & SS OR TH C & \\
\hline how & HOPI WHITE & SS NM HO D & SS NM SA L 1983 \\
\hline $\mathrm{hmu}$ & HOWLING MOB & PI 231298 & \\
\hline hmg & HOWLING MOB & SS IA DR G & USDA 1982 \\
\hline kwm & KENNEDY'S WHITE MIDGET & SS OR TH C & SS IA DR G \\
\hline $\operatorname{lmb}$ & LINDSEY MEYER BLUE & Univ. Wisconsin & \\
\hline luh & LUTHER HILL & SS NY CH M & SS ONT PI G \\
\hline mal & MALCOMBS & SS IA DR G & SS OH KN T 1984 \\
\hline mar & MANDAN RED & SS WI NE K & SS IA DR G 1991 \\
\hline mib & MIDNIGHT BLUE & SS KS CR T & SS WI EA T 1988 \\
\hline mis & MIDNIGHT SNACK & SS IA DR G & \\
\hline non & NO NAME & SS MN BE D & \\
\hline nue & NUETTA & PI 219886 & \\
\hline nut & NUETTA & PI 213796 & \\
\hline orb & ORCHARD BABY & SS CA AS S & SS IA DR G \\
\hline ore & OREGON EVERGREEN & PI 231299 & \\
\hline pac & PAIUTE CROSS & SS UT WOD & \\
\hline pec & PEASE CROSBY & PI 255983 & \\
\hline qua & QUEEN ANNE & SS IA DR G & SSOH KN T 1984 \\
\hline rhi & RHODE ISLAND & PI 245130 & \\
\hline seu & STOWELL'S EVERGREEN & PI 219893 & \\
\hline sew & STOWELL'S EVERGREEN & Univ. Wisconsin & \\
\hline sun & SUNSHINE & PI 219894 & \\
\hline sbb & SWEET BABY BLUE & SS NY HE C & \\
\hline tus & TUSCARORA & SS MN KE O & Burr, 1865 \\
\hline wbw & WEST BROOKFIELD WHITE & PI 255975 & \\
\hline whw & WHIPPLE'S WHITE & PI 231300 & \\
\hline wyu & WHIPPLE'S YELLOW & PI 231301 & \\
\hline wyg & WHIPPLE'S YELLOW & SS IA DR G & PI 231301 \\
\hline yuc & YUKON CHIEF & SS AK VA J & $\begin{array}{l}\text { Alaska Agr. Expt. } \\
\text { Sta. }\end{array}$ \\
\hline
\end{tabular}

${ }^{2}$ Seed with PI numbers was obtained from the North Central Plant Introduction Center, Ames, Iowa.

'The letters following SS are the codes from Seed Savers 1993 Yearbook (Adelman et al., 1993).

'Univ. Wisconsin is the sweet corn breeding program, Dept. of Agronomy, Univ. of Wisconsin-Madison.

"Seed Savers 1992 Yearbook (Adelman et al., 1992). 
Table 5. Groups of variables found in the 58 sweet corn cultivars

\begin{tabular}{lcl}
\hline \hline Group & Subgroup & Variables (traits $\left.{ }^{2}\right)$ \\
\hline 1 & 1 & DAT DAS FOL TAT SMU LEL LEW LEN PLH EAH TAL TBP TBS \\
2 & RUS TBT RON EAD KEL \\
3 & KEW NKR EAL \\
4 & LEO TIN \\
5 & EAS \\
6 & KRA \\
2 & 1 & KTY KSA COC KTH \\
2 & KFC PRO TID \\
3 & ANC SIC \\
\hline
\end{tabular}

${ }^{\overline{2}}$ See Table 2 for name and description of the traits.

man' type rowing. (Galinat, 1971; Tapley et al, 1934). Our data confirm its uniqueness.

These results are supported by an isozyme study on the same germplasm (Revilla and Tracy, 1995). In that study three of the six independent cultivars, 'Hidasta', 'Anasazi', and 'Hopi White' clustered with Mexican/Southwestern USA corns. Based on isozymes 'Country Gentleman' did not cluster with any other sweet corn (Revilla and Tracy, 1995).

Based on morphology, clusters 1 through 5 could be considered as one race which we propose be called "Northeastern Sweets". Given the history of these sweet corn cultivars it is likely that Northeastern Sweets are a subset of the race Northern Flint (Goodman and Brown, 1988). This grouping as well as the relationship with Northern Flint is supported by a phylogeny based on isozymes (Revilla and Tracy, 1995). However, rather than use a racial classification based on morphology, we believe that it is preferable to continue to define cultivars as sweet corn based on their use as a vegetable and on the presence of one or more genes that increase sugar levels in the endosperm. This is due to the introgression of nonsweet germplasm into modern sweet corn inbreds (Haber, 1945; Tracy, 1994) and the importance of Country Gentleman germplasm both per se (Tracy, 1994) and as a contributor to modem inbreds (Gerdes and Tracy, 1994, Gerdes et al., 1993).

\section{Literature Cited}

Adelman, A., S. Demunth, B. Idstrom, J. Thuente, and K. Whealy. 1993. Seed savers 1993 yearbook. Decorah, Iowa.

Adelman, A., S. Demunth, J. Thuente, and K. Whealy. 1992. Seed savers 1992 yearbook. Decorah, Iowa.

Bird, R. and M.M. Goodman. 1977. The races of maize. V. Grouping maize races on the basis of ear morphology. Econ. Bot. 34:471-481.

Camussi, A. 1979. Numerical taxonomy of Italian populations of maize based on quantitative traits. Maydica 24:161-174.

Camussi, A. 1980. Numerical taxonomy of Italian maize populations: Fatty acid composition and morphological traits. Maydica 25:149-166.

Galinat, W.C. 1971. The evolution of sweet corn. Massachusetts Agr. Expt. Sta. Bul. 591.

Gerdes, J.T., C.F. Behr, J.G. Coors, and W.F. Tracy. 1993. Compilation of North American maize breeding germplasm. Misc. Publ. CSSA, Madison, Wis.

Gerdes, J.T. and W.F. Tracy. 1994. Diversity of historically important sweet corn inbreds as determined by RFLPs, morphology, isozymes, and pedigrees. Crop Sci. 34:26-33.

Goodman, M.M. 1968. The races of maize. II. Use of multivariate analysis of variance to measure morphological similarity. Crop Sci. 8:693-698. Goodman, M.M. and W.L. Brown. 1988. Races of corn. In: G.F. Sprague and J. W. Dudley (eds.). Corn and corn improvement. 3rd ed. Amer. Soc. Agron. Madison, Wis.

Goodman, M.M. and E. Paterniani. 1969. The races of maize. III. Choices of appropriate characters for racial classification. Econ. Bot. 23:265-271.

Haber, E.S. 1945. Dent, flint, flour, and waxy maize for the improvement of sweet corn inbreds. Proc. Amer. Soc. Hort. Sci. 46:293-294.

Hallauer, A.R. and J.F. Miranda Fo. 1988. Quantitative genetics in maize breeding. 2nd ed. Iowa State Univ. Press, Ames.

Huelson, W.A. 1954. Sweet corn. Interscience Publ., New York.

IBPGR. 1991. Descriptors for maize. Intl. Maize and Wheat Improvement Center, Mexico City-Intl. Board Plant Genet. Resources, Rome.

Llaurado, M. and J. Moreno-Gonzalez. 1993. Classification of northern Spanish populations of maize by methods of numerical taxonomy. I. Morphological traits. Maydica 38:15-21.

Revilla, P. and W.F. Tracy. 1995. Isozyme variation and pylogenetic relationships among open-pollinated sweet corn cultivars. Crop Sci. (In press.)

Romesburg, H.C. 1984. Cluster analysis for researchers. Lifetime Learning Publications, Belmont, Calif.

Sanchez-G., J.J. and M.M. Goodman. 1992. Relationships among the Mexican races of maize. Econ. Bot. 46:72-85.

Sanchez-G., J.J., M.M. Goodman, and J.O. Rawlings. 1993. Appropriate characters for racial classification in maize. Econ. Bot. 47:44-59.

SAS Institute. 1989. SAS/STAT user's guide. version 6.09. SAS Inst., Cary, N.C.

Smith, J.S.C. and O.S. Smith. 1989. The description and assessment of distances between inbred lines of maize: The utility of morphological, biochemical, and genetic descriptors and a scheme for the testing of distinctiveness between inbred lines. Maydica 34:151-161.

Sneath, P. and R. Sokal. 1973. Numerical taxonomy. W.H. Freeman, San Francisco.

Tracy, W.F. 1993. Sweet corn. In: G. Kalloo and B.O. Bergh (eds.). Genetic improvement of vegetable crops. Pergamon Press, Oxford, England.

Tracy, W.F. 1994. Sweet corn. In: A.R. Hallauer (ed). Specialty types of maize. CRC, Boca Raton, Fla.

Tapley, W.T., W.D. Enzie, and G.P. Van Eseltine. 1934. The vegetables of New York. vol. 1. part. 3. Sweet corn. Rpt. New York State Agr. Expt. Sta., Albany.

Wellhausen, E.J., A. Fuentes, A. Hernandez, and P.C. Mangelsdorf. 1957. Races of maize in Central America. Natl. Acad. Sci., Natl. Res. Council, Washington D.C., Publ. 511. 